\title{
SZEMLE
}

\section{SUDÁR BALÁZS: DZSÁMIK ÉS MECSETEK A HÓDOLT MAGYARORSZÁGON. MTA BÖLCSÉSZETTUDOMÁNYI KUTATÓKÖZPONT, TÖRTÉNETTUDOMÁNYI INTÉZET, BUDAPEST, 2014. 653 LAP, 225 KÉP}

A kora újkori hazai müvészettörténet-írás is fontos kézikönyvvel gazdagodott most, hogy megjelent Sudár Balázsnak a hódoltsági török építészet egyházi emlékeinek hatalmas adattára. Erre aligha gondol az átlagos müvészettörténész olvasó, tekintve, hogy a testes kötet színtiszta orientális épületeket rendszerez és katalogizál. Csakhogy a magyarországi reneszánsz kutatása már egy ideje viaskodik a törökök, pontosabban fogalmazva az oszmán hódítók magyarországi művészeti hagyatékával, amint ezt hamarosan részletesen látni fogjuk. Viaskodik, illetve viaskodott, hisz e könyv megjelenéséig nem állt a rendelkezésére megfelelő összehasonlító anyag. Recenzióm két részből áll. Az első rövid ismertetése Sudár Balázs könyvének. A második a könyv adataiból kiindulva a müvészettörténet-írás néhány török problémáját próbálja vázlatosan áttekinteni.

Lássuk először tehát a kötet szerkezetét, nagy vonalakban. Az Előszó után tíz, római számmal jelzett nagy fejezet sorakozik, majd következik az Adattár. Maga a fejezetekre tagolt bevezető tanulmány is hatalmas munka, terjedelme közel százharminc lap. Felosztása heterogénnek látszik, a nézőpontok nem egységesek, de világosan értelmezhető, gyakorlatias tagolással szembesülünk. A fejezetek terjedelme is erősen eltér egymástól. Az I. a forrásokat tekinti át, először a muszlim-, másodszor a keresztény-, harmadjára a régészeti és művészettörténeti forrásokat (13-29). Az első két szakasz az írásos emlékeket és a képes ábrázolásokat veszi sorra, jól követhető beosztásban. A muszlim források aprólékos tárgyalása különösen hasznos, hisz fontosságuk könnyen belátható, tanulmányozásuk viszont speciális, turkológus felkészültséget kíván. Ez csak keveseknek van meg. A II. fejezet a Kutatástörténet címet viseli (30-34). Ez csupán rövid, váz- latos áttekintés, afféle ablaknyitás arra, amit még nem ismerünk kellő részletességgel. A III. - szintén rövid - fejezet terminológiai természetű: a „hódoltság” és a "török” fogalmát értelmezi (35-39). Az utóbbi időben megtanultuk, hogy ezekkel a régóta használatos szavakkal óvatosan kell bánni. A IV. fejezet az imahelyek szerepét tekinti át a muszlim társadalomban (40-46). A dzsámik és mecsetek nem absztrakciók, hanem eleven részei a hódoltság oszmán-török társadalmának. Az V. fejezet a muszlim kegyes alapítványokat, a vakufokat elemzi részletesen (47-52). Ezek az alapítványok tették lehetővé a vallási és oktatási intézmények - például a dzsámik - működését, és ezek üzemeltették a különböző jóléti intézményeket. Csak az uralkodói dzsámit finanszírozta az állam. A VI. fejezet a hódoltsági imahelyeket kategorizálja, több szempontból: áttekinti a számukat települések szerint, foglalkozik az elnevezésükkel, kitér a fenntartók és az alapítók szerepére (53-92). Ez szinte a konkrét bevezetése lehetne az Adattárnak. A következő (VII.) rész az imahelyek személyzetével foglalkozik (93-104). Ezek száma igen eltérő lehetett, kettőtől akár ötvenig is terjedhetett, s beletartozott mindenki, az imámtól a müezzinig vagy a - dzsámi mellett működő - iskola tanítójáig. A VIII. fejezet a hódoltsági dzsámikat tipologizálja (105-115), a IX. pedig összegyüjti az ismert emlékek kialakításának külső jellemzőit (116141). A X. fejezet az Összefoglalás (142). Ez után következik a terjedelmes Adattár (143-594). A kötetet a mintegy hatvanlapnyi Melléklet zárja (595-653). Itt található a rövidítésjegyzék (benne a felhasznált szakirodalom listájával), az idegen szavak és kifejezések magyarázata, valamint a földrajzi név- és személynév mutató. Ezek a segédletek rendkívül használhatóvá teszik ezt a hatalmas kötetet. 
A mintegy 450 lapos Adattár a kötet legsúlyosabb része. Ez a teljes hódoltság, vagyis a történeti Magyarország összes török imahelyét tartalmazza, a helységek betűrendjében haladva. Összeállítója az írásos forrásokból indult ki, de feldolgozta a régi térképeket, rajzokat, metszeteket éppúgy, ahogyan az archív fotókat, valamint a legújabb régészeti ásatási vagy falkutatási eredményeket. Minden jelenleg tudhatót. Mivel valamennyi adatnál megadta a forrást is, az objektum irodalma is összeáll. A rajzokon, térképeken, ha a helyzet nem egyértelmü, nyíl jelöli, mire kell figyelemmel lenni.

A legnagyobb városok adatai a leggazdagabbak, legterjedelmesebbek. Ilyen Buda, Eger, Esztergom, Székesfehérvár, Pécs. Megtalálhatók benne - nagy részletességgel tárgyalva - a híres épületek: a pécsi Kászim- és Jakováli Haszan dzsámi, és a szigetvári Ali pasa dzsámi is (413-417, 405-413, 496-499). Ezúttal azonban nem a híres, ma is álló néhány imahellyel kezdjük szemlénket, hanem az eltűntekkel. Azokkal, amelyeket a felszabadító háború után keresztény használatba vettek, de később lebontottak vagy a felismerhetetlenségig átépítettek. Ez volt ugyanis az általános tendencia; a két pécsi és a szigetvári dzsámi - ezekre később visszatérünk - a kivételek.

Egerben például a ferencesek használtak dzsámit (vagy mecsetet), amit 1750-ben bontottak le, amikor az új templomuk felépült. A török épület barokk berendezésének darabjait átvitték az új helyükre (253-254). A jezsuiták is ekkortájt bontották le azt a dzsámit, amelyben ténykedésüket elkezdték ugyanebben a városban (254). A ma is álló egri minaret épp egy olyan dzsámihoz (vagy mecsethez) tartozott, amelynek török kori történetét egyelőre nem ismerjük (255-258). Nevét sem; az irodalomban elterjedt „Kethudá-dzsámi” megnevezés biztosan téves. Az épületet először templommá alakították át (Szent József tiszteletére szentelve), s azt 1727-ben Erdődy Gábor püspök az irgalmas rendnek adományozta. ${ }^{1}$ 1841-ben tüntették el, miután megépült a rend új temploma. A minaret a maga nemében egészen kiváló alkotás, úgyhogy az az épület sem lehetett akármi, amelyhez tartozott.

Pesten a szerviták kaptak meg használatra egy dzsámit, azt, amelyik a mai Városház - az Invalidusok palotája - telkén állt (440-442). Hogy pontosan hol, egyelőre nem tudjuk. A pálosok is egy dzsámit kaptak meg Pesten; az átépített épületet 1782-ben bontották le (440). A helyét ennek sem ismerjük. A pesti török építésű imahelyek száma legalább négy volt; egyiknek sem sikerült meghatározni pontos koordinátáit. Ez a pesti belvárosban általános topográfiai probléma: itt - vagyis a szükebb
V. kerületben - a középkori ferences és a domonkos templomról sem tudjuk, hol álltak. Az uralkodói dzsámit az oszmánok minden bizonnyal Pesten is - mint mindenütt - a város főtemplomából alakították ki (442-445). Ez a belvárosi főplébánia-templom gótikus épülete volt, ahol meg is maradt a szentély déli falában a mihráb-fülke. A templom most folyó régészeti feltárása során is kerültek elő olyan nyomok, amelyek a török időkről szóló ismereteinket gazdagítják, ezek azonban egyelöre feldolgozás alatt vannak. Budán az uralkodói dzsámit a Mátyás-templomból alakították ki (190-196., 50-51. kép). A Schulek-féle átépítés során előkerültek a szentély másodlagos török ablakai; csak fotó maradt róluk. A ferencesek Székesfehérvárott is egy mecsetben kezdtek, az épület 1720-ban pusztult el (290). Siklóson az uralkodói dzsámit az Ágostonrendiek gótikus templomából alakították ki (457). Ennek restaurálása felszínre hozta a gótikus freskókat a szentélyben, de a török használatnak jelentős nyoma nem került elő. ${ }^{2}$

Ma is vannak az országban több helyütt is olyan katolikus templomok, amelyek falaikban örzik az eredeti török imaház maradványait. Pécsett a Szent Ágoston-templom felmenő falaiban ott lapulnak a bőrcserzők egykori dzsámijának elemei (394-396., 121-122. kép), Budapesten pedig a budai Fő utcában, a kapucinusok templomában látható - kibontva - Tojgun pasa dzsámijának néhány részlete (217-220., 56. kép). Van olyan barokk templom is, amelyben eddig nem került sor alapos falkutatásra, így csupán feltételezni lehet, hogy dzsámit rejt magában. Ilyen Budapesten, a Tabánban álló Alexandriai Szent Katalin-templom, amelynek hajójában Sudár Balázs szerint ott lappang a török épület, Ibrahim csávus dzsámija (220-225., 57. kép).

Talán ilyen rövid áttekintés is érzékelteti, hogy a könyv adattári része megkerülhetetlen kézikönyve lesz nemcsak a történeti stúdiumok müvelőinek, hanem a középkorral és a kora újkorral foglalkozó régészeknek és a müvészettörténészeknek is.

Emeljünk ki egyetlen, ám igen fontos müvészettörténeti problémát. A magyarországi reneszánsz kutatása már egy ideje - mint a bevezetőben említettem - próbálkozik a törökök, pontosabban fogalmazva az oszmán hódítók magyarországi - hódoltsági - művészeti hagyatékának integrálásával. A magyarországi török építészeti emlékek recepciójának története sajnos összességében feldolgozatlan, ${ }^{3}$ és ezt a nagy munkát egyhamar nem is lehet pótolni. A könyvben mindenesetre ott rejlik ez a recepciótörténet is, szakirodalmi adataiból kiindulva fel lehetne tárni a kérdés megközelítőleg teljes historiográfiáját. 
Mikortól kezdte a hazai művészettörténet-írás beemelni a török építészet emlékeit saját narratívájába? Az egyik első hazai kripto-müvészettörténet, vagyis Pasteiner Gyulának Az Osztrák-Magyar Monarchia írásban és képben címü sorozatban írott összefoglalói közül a Dunántúl müvészetének történetét áttekintő cikkében már szerepel röviden a török korszak: „A török uralom mind azért, amit e vidéken elpusztított, vagy aminek elpusztulását elősegítette, kárpótlásul vajmi kevés saját alkotású építészeti müvet hagyott maga után. Pécs dicsekedhetik a legkiválóbb török építményekkel." ${ }^{4}$ A pécsi török emlékek - átépített állapotuk ellenére - már ekkor is látványosak lehettek: a Kászimés a Jakováli Haszan dzsámi, valamint Idrisz baba türbéje szerepel itt, mindhárom név nélkül. Ezeket a helytörténetírás is számon tartotta később: a város müvészeti emlékeit bemutató Magyar Müvészet 1929. évi 8. számában külön bekezdés szólt a város török kori emlékeiről. ${ }^{5}$

Az önálló hazai építészettörténet-írás kezdettől fogva integrálta a török kor emlékeit. Foerk Ernő - építész, ipariskolai tanár - 1917-ben a szokásos szünidei felmérések tárgyául ezeket az emlékeket választotta. ${ }^{6}$ 1929-ben írott rövid építészettörténetében is kitért erre a korszakra. ${ }^{7}$ A hasonló összefoglalások ugyanilyen mintát követtek a továbbiakban is. Rados Jenő Magyar épitészettörténetébe beiktatott egy török fejezetet, bár a szerző pontosan felismerte, hogy ezeknek az épületeknek semmiféle hatásuk nem volt a korabeli magyar építészetre. ${ }^{8}$ Ez az irány később is érvényes maradt: 1998-ban a magyarországi építészet történetét bemutató - eredetileg amerikai közönségnek szánt ${ }^{9}$ - monográfiában is jókora önálló török fejezet kapott helyet. ${ }^{10} \mathrm{~A}$ Kossuth Kiadó magyar építészettörténeti sorozatában Feld István írta a késő reneszánsz és kora barokk kötetet (2002). A török fejezet a könyv végén szerepelt, gondosan elkülönítve a történeti stílusokat bemutató szövegtől és képanyagtól. ${ }^{11}$ A megszokott épület-sorozatot kibővítette a török erődépítészet néhány példájával.

A magyar művészettörténeti összefoglalók sokáig nem tértek ki a török épületekre; sem a pécsiekre, sem a többire. A két világháború között sem Péter András, ${ }^{12}$ sem Divald Kornél, ${ }^{13}$ sem Hekler Antal ${ }^{14}$ vagy Balogh Jolán ${ }^{15}$ nem foglalkozott a hódoltság török müvészetével.

Az első reprezentatív magyar müvészettörténeti kézikönyv, amely a Magyar Tudományos Akadémia égisze alatt készült, vagyis $A$ magyarországi müvészet története (1956) sem szánt neki egyetlen bekezdésnél többet. Garas Klára tárgyilagosan regisztrálta a tényeket, vagyis a kevés számú új, reprezentatív török épületet, és azok stílusának hatástalanságát a korabeli magyar építészetre: „Közelebbi hatása, kapcsolata ... a török mesterek alkotásainak hazai építészetünk fejlődésével nem volt." A hódoltság magyar müvészete valamivel hosszabb bekezdést kapott. Egészében véve azonban nem volt igazán lényeges részlete a kötetnek. ${ }^{16} \mathrm{Az}$ átdolgozott kiadásban ennek a két bekezdésnek korrekt alcímet adtak: A török hódoltság területe. A szöveg nem változott. ${ }^{17}$

A török müvészet önálló fejezetként először igen későn, csak az 1983-ban megjelent, Aradi Nóra szerkesztette egykötetes magyarországi művészettörténetben jelentkezett saját föcímmel: „A török müvészet emlékei Magyarországon". ${ }^{18}$ Erősen túlreprezentálva, vagyis a jelentőségénél jóval nagyobb terjedelemben. A fejezetet Feuerné Tóth Rózsa (1928-1985) írta, aki a reneszánsz fejezeteket is jegyezte. ${ }^{19}$ Jellemző, hogy a Corvina Könyvtár, a késő középkori budai királyi udvar egyik legnagyobb hatású kulturális teljesítményének bemutatására jó, ha fél oldal jutott, ezzel szemben a török építészet gyér számú emlékeire öt lap. És távolról sem a teljes anyag (ez Sudár Balázs könyvéből jól látszik), csupán tucatnyi épület - dzsámi, türbe, minaret, fürdő - alapján, amelyeket a műemlékvédelem éppen restaurált. Részletes tárgyalásuk során fel sem vetődött az akkulturáció kérdése, az, ami egyedül indokolttá tehette volna ezt a súlyozást.

A „kétkötetes” új változata, A magyar[országi] müvészet története (2001) tudatosan szakította meg ezt az új keletü hagyományt, és visszatért a régi felosztáshoz; az oszmánok nem kaptak önálló fejezetet, ám a hódoltsági magyar müvészet is reflektálatlanul maradt. ${ }^{20}$ A Corvina Kiadó „rejtett” magyar múvészettörténeti sorozatában sem a reneszánsz, sem a barokk kötet nem tért ki külön az oszmán hódítók müvészetére, viszont a hódoltságot sikerült végre integrálni. ${ }^{21}$ Legutóbb szintén a Corvina Kiadó jelentett meg reprezentatív összefoglalást a magyar müvészetről (2009, 2015²). Ebben a török építészet elszeparált részt kapott, a jelenség különállóságát hangsúlyozva Magyarországon. ${ }^{22}$

A magyarországi oszmán müvészet bemutatásával kapcsolatban kialakult múvészettörténeti értékelés nem mondható éppen statikusnak. Nem csupán arról van szó, hogy 1945 előtt a kutatók nem érdeklődtek kellő intenzitással nálunk az oszmán hódítók építészete iránt, hanem inkább arról, hogy korábban ezek az épületek nem voltak láthatók úgy, ahogyan ma. Abban az állapotukban rejtőzködtek, amelybe a 18-19. század burkolta őket. Először a pécsi Kászim pasa dzsámi vette fel ismét a török mimikrit, a modern magyar müemlékvé- 
delem megújulása idején, a harmincas évek végén. Látványos megjelenését a többi is az intézményes müemlékvédelemnek köszönhette - már 1945 után -, amelynek esztétizáló purizmusa könyörtelenül érvényesült a barokkal szemben, és felszínre hozta - és ahol tehette, kiemelte - a keleti elemeket. Sudár Balázs monumentális adattárából kiolvasható a pontos kronológia: a pécsi Jakováli Haszan dzsámi 1962-től működik múzeumként (405-413), s 1960-1965 között kapta teljesen vissza muszlim külsejét a Kászim pasa dzsámi a főtéren (413-417). Szigetváron is nagyjából ugyanebben az időben erőszakolták vissza Ali pasa dzsámiját a plébániatemplom épületébe (496-499), és még szerencse, hogy Dorffmaister István kupolafreskója legalább részben megóvta a belső reprezentatív barokk díszítését. ${ }^{23} \mathrm{Az}$ egyik utolsó rekonstrukciós helyreállítás az esztergomi Uzsicseli Hadzsi Ibrahim dzsámi volt, már az ezredforduló után (280-281). E dátumok nagyjából követik az 1945 utáni hazai müemlékvédelem kronológiáját. A fénykor a hatvanas-hetvenes évekre esett. ${ }^{24}$

Az iparművészet, amelynek emlékei pedig mutathatnának némi átjárhatóságot a két kultúra, a magyar és az oszmán között, nem került a kutatás fókuszába, mivel az iparművészet a tradicionális - építészet, szobrászat, festészet - felosztásban a narratíva hátsó, lényegtelen traktusába tartozott. A hódoltsági török müvészet integrálásának alapja azonban nem lehet pusztán területi, nem lehet mechanikus (vagyis, hogy ami az országhatárokon belül van, az automatikusan tárgyalandó), hanem lényegi kellene, hogy legyen. A politikai korrektség a tudományban nem célravezető. A különböző művészeti alkotásokat felhasználó közösségek, társadalmi rétegek igényéből kellene kiindulni. Ez a közösség pedig egyáltalán nem akarta integrálni az oszmán hódítókat, sem maga nem akart közéjük integrálódni. ${ }^{25}$ (Tekintsünk el, nagyvonalúan, a ritka kivételektől.) A hódoltság magyarsága megőrizte keresztény - katolikus, lutheránus, református, unitárius - identitását, amit a művészet eszközei is kifejeztek. Nem volt ez másképp a túlsó oldalról nézve sem: „Az itteni muszlimság a hódoltság egész ideje alatt erős várfalakkal védett, katonaság által őrzött igazgatási központokba visszahúzódva, kisebb-nagyobb iszlám szigeteket alkotott egy mindvégig keresztény országban, amelynek lakosai lényegében alig kerültek kapcsolatba az új hit tanaival." ${ }^{26}$ Kulcskérdés az akkulturáció: ${ }^{27}$ a török bársony padlótakaróból vagy a kaftánok selyemszövetéből így lett miseruha, a turbánból úrasztali kendő, az imaszőnyegből pedig esetleg asztalterítő. ${ }^{28}$

Sudár Balázs könyve ezekre a müfajokra természetesen nem tér ki. Az építészeten belül is csak az imahelyekkel foglalkozik. Okosan szükítette a témáját, a hatalmas anyag jól kezelhető, könnyen áttekinthető maradt. Rajtunk múlik, hogy élünk-e az általa nyújtott lehetőségekkel. Adataiból kiindulva jóval biztosabb kézzel rajzolhatjuk majd meg a magyarországi hódoltság kultúrájának oszmán-török részét, és találhatjuk meg valódi helyét a magyarországi müvészet történetében.

Mikó Árpád

\section{JEGYZETEK}

1 Heves megye műemlékei, II. Szerk. Voit Pál. Budapest 1972, 325; Sugár István: Az egri püspökök története. Eger 1984, 398.

2 Lốvei Pál: A siklósi plébániatemplom szentélye és középkori falképei. In: Múemlékvédelmi Szemle 5 (1995/12.) $177-214$.

3 Vö. Gerő Győző: Az oszmán-török építészet Magyarországon. (Dzsámik, türbék, fürdők.) (Müvészettörténeti Füzetek, 12.) Budapest 1980, 11-16.

4 Pasteiner Gyula: Építészeti emlékek a Dunán túl. In: Az Osztrák-Magyar Monarchia írásban és képben. 16. kötet. Budapest évszám, lapszám.

5 Szőnyi Ottó: Pécs műemlékei. Magyar Művészet V. $1929,546-551$.

6 A budapesti Magyar Állami Felső Építőipariskola szünidei felvételei. VI. füzet. Török emlékek Magyarországon. Budapest 1917. Az egész sorozatnak megjelent reprint kiadása: A Magyar Királyi Állami Felső Építő Ipariskola Szünidei Felvételei, 1912-1942. Budapest, Terc Kiadó, 2002.

7 Foerk Ernő: A magyar építőmüvészet rövid története magyar műemlékek nyomán. Kecskemét 1929, 167-175.
8 Rados Jenô: Magyar építészettörténet. Budapest 1975³ 165-172. Az első kiadás 1961-ben, a második 1972ben jelent meg.

9 The Architecture of Historic Hungary. Ed. József Sisa - Dora Wiebenson. Cambridge, Mass. 1998.

10 Farbaky Péter: Késő gótika és kora reneszánsz. Török építészet Magyarországon. Késő reneszánsz. In: Magyarország építészetének története. Szerk. Sisa József - Dora Wiebenson. Budapest, 1998. 63-107., a török rész: 85-88.

11 Feld István: Magyar építészet. Késő reneszánsz és kora barokk. Budapest 2002, 156-172.

12 Péter András: A magyar múvészet története, I-II. Budapest 1930.

13 Divald Kornél: Magyar művészettörténet. (Szent István könyvek, 47.) Budapest 1927.

14 Hekler Antal: A magyar múvészet története. Budapest [1934]; Anton Hekler: Ungarische Kunstgeschichte. Berlin 1937.

15 Balogh Jolán: A késő-gótikus és a renaissance-kor művészete. In: Magyar renaissance. Magyar Művelődéstörténet, 2. Szerk. Domanovszky Sándor. Budapest [1939], 509-584. 
16 Garas Klára: A barokk művészet kialakulása és elterjedése Magyarországon (1604-1711). In: A magyarországi múvészet a honfoglalástól a XIX. század végéig. Szerk. Dercsényi Dezső. Budapest, 1964³ , 398-399., 315-316. kép. (A magyarországi művészet története, I-II. Szerk. Fülep Lajos.)

17 Garas Klára: A barokk művészet kialakulása. 1604-1700. In: A magyarországi művészet története, I-II. Főszerk. Fülep Lajos, szerk. Dercsényi Dezső - Zádor Anna. Budapest 19735 , 270., 410-411. kép.

18 Feuerné Tóth Rózsa: A török múvészet emlékei Magyarországon. In: A múvészet története Magyarországon a honfoglalástól napjainkig. Szerk. Aradi Nóra. Budapest, 1983, 208-214.

19 Erről részletesebben írtam: Mikó Árpád: Reneszánsz, magyar reneszánsz, magyarországi reneszánsz. Részletek egy stíluskorszak kutatásának történetéből. In: Mátyás király öröksége. Késő reneszánsz művészet Magyarországon (16-17. század). I-II. Szerk. Mikó Árpád - Verő Mária. Magyar Nemzeti Galéria, Budapest 2008, II., 131-134.

20 Galavics Géza - Marosi Ernő - Mikó Árpád - Wehli Tünde: Magyar[országi] művészet a kezdetektől 1800-ig. (Egyetemi Könyvtár) Budapest, 2001, passim.

21 Mikó Árpád: A reneszánsz Magyarországon. (Stílusok - korszakok, [3.]) Corvina Kiadó, Budapest 2009; Igaz Rita: A barokk Magyarországon. (Stílusok - korszakok, [4.]) Budapest, 2007.
22 Bellák Gábor - Jernyei Kiss János - Keserü Katalin Mikó Árpád - Szakács Béla Zsolt: Magyar művészet. Budapest, 2009, 146-147.

23 Galavics Géza: Dorffmaister István történeti képei. In: Dorffmaister István emlékkiállítása. Szerk. Kostyál László - Zsámbéky Monika. Szombathely 1997, 86-87. 45-48. kép.

24 Részletesebben erről Mikó Árpád: A magyarországi oszmán-török építészet szerepe művészettörténetünkben. Műemlékvédelem és múvészettörténet-írás. Megjelenés alatt a „Vallások a török hódoltság korában” című, Ittzés Gábor által szerkesztett tanulmánykötetben.

25 Varga Szabolcs: Devictus vincit. A Magyar Királyság sorsfordulói a közép- és kora újkor határán (1439-1566). Magyar Tudomány 177 (2016/9) 1030-1040.

26 Varga Szabolcs: Irem kertje. Pécs története a hódoltság korában (1526-1686). Pécs 2009, 163. Vö.: Gerelyes Ibolya: A törökös-balkáni ékszertípusok elterjedése a hódoltságban. In: Identitás és kultúra a török hódoltság korában. Szerk. Ács Pál - Székely Júlia. Budapest 2012, 221-234.

27 Pásztor Emese: Cafrang, csótár, jancsika. A magyar nyelvű források szerepe a hódoltság kori török iparmüvészet történetének kutatásában. In: Identitás és kultúra a török hódoltság korában... i. m. 235-248.

28 Mátyás király öröksége... i. m. I., 145-146 (IV-12.), 146 (IV-13.), 187 (VI-25.), 233. (VIII-14.) 